\title{
O papel da educação na cooptação ideológica em Gramsci e Freire
}

Bruno Botelho Costa

Mestrando em Educação pela Universidade Estadual de Campinas

\section{Resumo}

Este trabalho tem por objetivo discutir o processo de cooptação ideológica em Antonio Gramsci e Paulo Freire. Procuraremos ver nas ponderações sobre a contradição Estado/Sociedade civil e sua relevância na disputa da hegemonia de classe em Gramsci e contradição entre teorias de ação dialógica e antidialógica em Freire, a possível associação entre suas perspectivas pedagógicas e ideológicas. Para tanto, abordaremos a questão da educação em Freire e Gramsci no intuito de ver nas concepções de intelectual orgânico e do educador-educando dialógico aproximações entre os contrapontos desses autores à referidas contradições.

Palavras-chave: Gramsci; Freire; Ideologia.

\begin{abstract}
This paper intents to discuss the process of ideological cooptation in Antonio Gramsci and Paulo Freire. We try to observe in considerations on State/Civil society contradiction and class hegemony dispute in Gramsci and dialogical/anti-dialogical theoretical contradiction in Freire, the possible association between their pedagogical and ideological perspectives. Therefore, we shall approach the education matter in Freire and Gramsci in order to find in the organic intellectual and dialogical educator-educating conceptions proximities between these authors counterpoints to the referred contradictions.
\end{abstract} Keywords: Gramsci; Freire; Ideology. 


\section{Introdução}

$\mathrm{E}$

ste trabalho visa analisar as contribuições de Gramsci e Freire para o debate educacional mediante a incursão em problemáticas apontadas em suas obras, nas quais se é passível de se verificar aproximações e distanciamentos entre este dois pensadores e educadores no que tange à cooptação ideológica.

Nosso intuito é o de assinalar conceitos-chave que fundamentam e delineiam o conteúdo e a forma de suas perspectivas filosóficas e pedagógicas, desdobrando-os e interpretando possíveis pontes conceituais que surgem do contraponto entre um e outro.

De Gramsci, buscamos recuperar a definição de intelectual orgânico, seu caráter político e ideológico de classe, enquanto esteio da perspectiva gramsciana de educação.

De Freire, trazemos a discussão da educação dialógica e da construção nas práticas educacionais da comunhão dos homens através do diálogo e do reconhecimento do outro enquanto sujeito.

Com estas duas questões, buscamos uma interface dos dois conceitos que motive uma reflexão mais ampla sobre a cooptação ideológica e sua presença nas teorias educacionais de ambos os autores, interrogando em que medida as contradições do Estado ampliado, representadas na interação entre sociedade politica e sociedade civil, se fazem sentir no espaço educacional.

\section{Justificativa}

Consideramos os conceitos gramscianos e freirianos fundamentais para análise da cooptação ideológica em educação. A partir dos conceitos mencionados, é possível indagar como ideologia, enquanto consciência histórica mediadas pelas condições sociais da organização do trabalho, se faz presente nas relações educador-educando, indo além do propósito educativo explícito, sem, contudo, deixar de ter nela um forte veículo de transmissão de formação de consensos nem sempre unânimes e por vezes contraditórios. 


\section{Objetivos}

- Investigar, nas concepções de Gramsci e Freire, o sentido filosófico genérico da visão de mundo do homem comum e como as características decorrentes de sua especialização nas camadas intelectuais institucionalizadas refletem a vinculação ideológica de seus membros a uma classe social.

- Pesquisar, nestes autores, o papel do educador e do intelectual novo enquanto agente de resistência à cooptação ideológica tradicional e propositor de uma cultura revolucionária.

- Explicitar, na leitura de Gramsci e Freire, os diferentes métodos e formas de organização da cultura adotadas para a criação e organização cultural, bem como os meios empregados por eles para conseguir a adesão da massa a sua orientação política, sua postura frente às contradições internas do Estado que se ampliam nas sociedades política e civil e sua concepção e atuação enquanto liderança do e no movimento revolucionário.

- Suscitar, a partir de Gramsci e Freire, a discussão sobre o papel da escola enquanto espaço-formador político e ideológico, a composição ideológica de suas forças sociais e as conseqüências de seu ensino no que tange à conscientização dos seus componentes, educadores e educandos.

\section{Metodologia}

A pesquisa que resultou neste trabalho possuiu, como aporte metodológico, a análise dos conceitos referidos no tópico "Introdução" a partir de quatro obras principais em Gramsci e Freire respectivamente: Concepção Dialética da História/Os Intelectuais e a Organização da Cultura e Educação como Prática de Liberdade/Pedagogia do Oprimido. Além destas, contamos alguns apontamentos de comentadores: Eugenio Garin, em Com Gramsci; Moacir Gadotti, em Concepção Dialética da Educação; Norberto Bobbio, em Ensaios sobre Gramsci e o conceito de sociedade civil. 


\section{Bibliografia consultada}

BOBBIO, Norberto. Ensaios sobre Gramsci e o conceito de sociedade civil. São Paulo: Paz e Terra, 1999.

FREIRE, Paulo. Educaşão como Prática de Liberdade. Rio de Janeiro: Paz e Terra, 1975.

FREIRE, Paulo. Pedagogia do Oprimido. Rio de Janeiro: Paz e Terra, 1983.

GADOTTI, Moacir. Concepscão Dialética da Educaşão: um estudo introdutório. São Paulo: Cortez/Autores Associados, 1987.

GARIN, Eugenio. Com Gramsci. Porto: Campo das Letras, 2005.

GRAMSCI, Antonio. Concepşão Dialética da História. Rio de Janeiro: Civilização Brasileira, 1981.

GRAMSCI, Antonio. Os Intelectuais e a Organização da Cultura. Rio de Janeiro: Civilização Brasileira, 1979. 